\title{
EFFECTIVENESS OF PRE PRP INJECTION AND POST ELEVATION FLAP AT EXTENDED RANDOM FLAP RAT SKIN
}

\author{
Thomas Eduardus Sudrajat Wahyu Nugroho, Sitti Rizaliyana, David S Perdanakusuma \\ Department of Plastic Reconstrutive and Aesthetic Surgery, Faculty of Medicine, Universitas Airlangga, \\ Dr. Soetomo General Hospital, Surabaya, Indonesia
}

\section{ABSTRACT}

Closure of the defect with a random skin flap is constrained by the extent of the defect area. Several studies have shown the benefits of administration of PRP (Platelet Rich Plasma) in random skin flap. The purpose of this study is to compare the effect of PRP injection given before flap elevation, after flap elevation and control on the extended random skin flap procedures in rats. This was an experimental study with randomized posttest-only control group design $(n=27$, divided into 3 treatment groups) that compare the effectiveness of PRP injection 24 hours prior to the elevation of the flap, after the elevation of the flap, and control in the extended random skin flap in rats. Random skin flap is made in the ratio 1: 5 on the rat skin. Measurement of viable area were observed on days 1, 7 and 14. There were significantly increased viability of random skin flap on the group with PRP injection 24 hours prior flap elevation compared to other group of treatment. The average of viability on day first $39 \% \pm 13 \% ; 42 \% \pm 34 \% ; 62 \% \pm 14 \%$. On day 7 th $24 \% \pm 13 \% ; 36 \% \pm 26 \% ; 62 \% \pm 12 \%$. On day 14 th $16 \% \pm 15 \% ; 28 \% \pm 22 \% ; 60 \% \pm 11 \%$. Injection of PRP on extended random skin flap on rat 24 hours before flap elevation increase viability of the flap compared to control group and group which receive PRP injection on extended random flap on rat skin after elevation of the flap. Viability increased due to angiogenesis stimulation after PRP injection.

Keywords: Platelet Rich Plasma; flap survival; extended random skin flap

\section{ABSTRAK}

Penutupan kerusakan dengan flap kulit acak dibatasi oleh luasnya area kerusakan. Beberapa penelitian menunjukkan manfaat pemberian PRP (Platelet Rich Plasma) pada flap kulit acak. Tujuan dari penelitian ini adalah untuk membandingkan pengaruh injeksi PRP yang diberikan sebelum Elevation flap, setelah Elevation flap dan kontrol terhadap prosedur extended random flap kulit pada tikus. Penelitian ini merupakan penelitian eksperimental dengan rancangan randomized posttest-only control group design ( $n=27$, dibagi menjadi 3 kelompok perlakuan) yang membandingkan efektivitas injeksi PRP 24 jam sebelum Elevation flap, setelah Elevation flap, dan kontrol. di flap kulit acak diperpanjang pada tikus. Flap kulit acak dibuat dengan perbandingan 1: 5 pada kulit tikus. Pengukuran luas viabel diamati pada hari ke 1, 7 dan 14. Terdapat peningkatan viabilitas yang bermakna pada kelompok yang diberi injeksi PRP 24 jam sebelum pengangkatan flap dibandingkan dengan kelompok perlakuan lainnya. Rata-rata viabilitas pada hari pertama 39\% $\pm 13 \% ; 42 \% \pm 34 \% ; 62 \% \pm 14 \%$. Pada hari ke $724 \% \pm 13 \%$; $36 \% \pm 26 \% ; 62 \% \pm 12 \%$. Pada hari ke $1416 \% \pm 15 \% ; 28 \% \pm 22 \% ; 60 \% \pm 11 \%$. Injeksi PRP pada perluasan flap kulit acak pada tikus 24 jam sebelum peninggian flap meningkatkan viabilitas flap dibandingkan dengan kelompok kontrol dan kelompok yang menerima injeksi PRP pada perluasan flap acak pada kulit tikus setelah peninggian flap. Viabilitas meningkat karena stimulasi angiogenesis setelah injeksi PRP.

Kata kunci: Platelet Rich Plasma; kelangsungan hidup penutup; flap kulit acak diperpanjang

Correspondence: Thomas Eduardus Sudrajat Wahyu Nugroho, Department of Plastic Reconstrutive and Aesthetic Surgery, Faculty of Medicine, Universitas Airlangga, Dr. Soetomo Academic Hospital, Jl Mayjen Prof Dr Moestopo 6-8, Surabaya 60286, Indonesia. E-mail: eduardussudrajat@gmail.com

pISSN:2355-8393 • eISSN: 2599-056x • doi:

- Fol Med Indones. 2020;56:186-191 • Received 13 Dec $2018 \bullet$ Accepted 13 Jun 2019

- Open access under CC-BY-NC-SA license • Available at https://e-journal.unair.ac.id/FMI/

\section{INTRODUCTION}

In recent years, surgical procedures that leave extensive defects that are difficult to cover primarily is increasing. The extensive defect causes exposure of important structures such as blood vessels, tendons and bones, so that reconstructive surgery for the closure of the defect with the flap also has a significant increase. In Dr. Soetomo General Hospital, the use of random skin flaps to close defects has become a routine procedure. 
Platelet Rich Plasma (PRP) is a product of blood plasma, rich in platelets and a kind of natural source of growth factors and fibrinogen which is thought to accelerate healing of soft tissue (Carlson et al 2002). Kim et al in 2013 proved that injecting PRP on axial flaps can increase the success of the flap (reducing necrotic area) in rats. Giving injection of PRP in the skin flap can increase the success rate through angiogenic and arteriogenic mechanisms (Kim et al 2013). In this study the researchers wanted to find out the effectiveness of PRP in extended random skin flap, which was pre-injected and post-action flap elevation in increasing the success of extended random skin flap in rats.

\section{MATERIALS AND METHODS}

\section{Preparation of Platelet-Rich Plasma}

All of the procedures were approved by the Ethics Committee of the Faculty of Veterinary Medicine, Universitas Airlangga. Winstar male adult males rats (200-300 grams) were given ketamine. After sedation, intracardiac blood was taken in 3 rats. Rat blood was then processed into PRP. PRP was made from $3 \mathrm{ml}$ of aspiration of rat intracardiac blood mixed with $0.5 \mathrm{ml}$ of anticoagulant in the form of a solution of Anticoagulant Citrate Dextrose (ACD) through twice intracardiac blood transfusion. The first centrifuge, which is a hard spin with a $4000 \mathrm{rpm}$ centrifuge for 10 minutes, separates intracardiac blood into three layers from top to bottom, namely the plasma layer, buffy coat layer and erythrocyte layer. For soft spin centrifuging, the top two layers, the plasma layer and buffy coat, are separated into another tube and then centrifuged at a speed of $2000 \mathrm{rpm}$ for 5 minutes. The second centrifuge separates into two layers, namely the platelet-rich plasma layer below and the plasma layer with a slightly platelet count above. The top layer is taken by leaving a layer of platelet concentrate in the plasma. This concentrate is then mixed with $0.1 \mathrm{ml}$ of calcium chloride $(\mathrm{CaCl} 2) 10 \%$ to activate platelets (De Rossi et al 2009). This PRP is then immediately injected into the flap. Pre-elevation PRP injection flap is given as much as $0.2 \mathrm{cc}$ in total done 24 hours beforehand at 5 points with a distance of $1 \mathrm{~cm}$ from the proximal flap.

\section{Extended random skin flap}

In this study rats were given a premedicated drug with atropine $0.02 \mathrm{mg} / \mathrm{kgBW}$ and acipromasin $0.1 \mathrm{mg} / \mathrm{kgBW}$ then given ketamine (Ketalar ${ }^{\circledR}$, Parke Davis) at a dose of $0.5-1 \mathrm{mg} / \mathrm{kgBW}$, after which an aseptic procedure was performed/antiseptic in the back region of rats that have been given PRP before, or in the back region of rats that have not been given PRP. Rats will get 3 treatments (given PRP before elevation flap, PRP after elevation flap, and control) and specimen collection and examination will be carried out with Visitrek $®$ (day 21), so that a total of 27 rats are needed.

\section{Area of viable flap}

The area of the viabel is seen regularly. Namely at 1,7 and 14 days post elevation using a Visitrek ${ }^{\circledR}$ tool. The viable area of the flap is marked by the skin color of the rats that fits the surrounding tissue, warm touch, $<2$ seconds CRT. In this study it was measured as a percentage of the total flap area, this was to avoid any bias due to the flap contraction factor. Data from the study were obtained from measurements of extended random skin flap and the area that was still viable. Measurements were carried out by researchers with transparent markers and paper, the data obtained were then measured in extent by Visitrek ${ }^{\circledR}$. The data obtained were analyzed using the Kolmogorov-Smirnov OneSample method and the research data were analyzed using Independence Sample T-Test with SPSS 17.0 software.

On day 0 the elevation of skin flaps was carried out on the backs of rats measuring $1 \mathrm{~cm} \times 5 \mathrm{~cm}$ in the $\mathrm{K}$ and $\mathrm{P} 1$ groups, in P2 group PRP injections were carried out in the area where the skin flap elevation would be carried out. The evaporated skin flap is sewn back into the skin to prevent a change in position, put vaseline paper under the flap to prevent imbibition of nutrients from below.

Measurement of necrotic area was carried out on days 1, 7 and 14. Measurements were made by means of the necrotic area being copied on transparent paper, measuring using a digital visitrak. The research treatment process can be seen in Figure 1 and 2. Data from the results of this study are in the form of data on the area of the viable flap on male back rats (Rattus norvegicus strain Wistar). Data on viability of mouse skin flaps is data with a ratio scale.

\section{RESULTS}

The average area of the viable area in the control group is $39 \%$ with a standard deviation of $13 \%$ on the first day, on the 7 th day with an average of $24 \%$ with a standard deviation of $13 \%$, while on the 14 th day with an average of $16 \%$ and a standard deviation of $15 \%$. In the pre-elevation group PRP injection treatment group the mean value on the first day of observation was $62 \%$ with a standard deviation of $14 \%$, on the 7 th day with a mean of $62 \%$ and a standard intersection of $12 \%$ while on the 14th day with an average of $60 \%$ and standard deviation $11 \%$. 
Table 1 . The average of viable area

\begin{tabular}{ccccc}
\hline Treatment & $\begin{array}{c}\text { Without PRP } \\
(\%)\end{array}$ & $\begin{array}{c}\text { PRP Post Elevation } \\
(\%)\end{array}$ & $\begin{array}{c}\text { PRP Pre Elevation } \\
(\%)\end{array}$ & $p$ \\
\hline Viability Flap Day-1 & $39 \pm 13$ & $42 \pm 34$ & $62 \pm 14$ & 0.054 \\
Viability Flap Day-7 & $24 \pm 13$ & $36 \pm 26$ & $62 \pm 12$ & 0.000 \\
Viability Flap Day-14 & $16 \pm 15$ & $28 \pm 22$ & $60 \pm 11$ & 0.000 \\
\hline
\end{tabular}

Table 2. Paired-sample statistics

\begin{tabular}{|c|c|c|c|c|}
\hline \multicolumn{5}{|c|}{ Paired Samples Statistics } \\
\hline & & Mean $(\%)$ & $\begin{array}{c}\text { Mean Difference } \\
(\%)\end{array}$ & $p$ value \\
\hline \multirow{2}{*}{ Pair 1} & Without PRP D-1 & 38.6807 & \multirow{2}{*}{14.32738} & \multirow{2}{*}{0.009} \\
\hline & Without PRP D-7 & 24.3534 & & \\
\hline \multirow{2}{*}{ Pair 2} & Without PRP D-1 & 38.6807 & \multirow{2}{*}{22.37103} & \multirow{2}{*}{0.000} \\
\hline & Without PRP D-14 & 16.3097 & & \\
\hline \multirow{2}{*}{ Pair 3} & Without PRP D-7 & 24.3534 & \multirow{2}{*}{08.04365} & \multirow{2}{*}{0.016} \\
\hline & Without PRP D-14 & 16.3097 & & \\
\hline \multirow{2}{*}{ Pair 4} & PRP Post Elevation D-1 & 41.9643 & \multirow{2}{*}{6.30581} & \multirow{2}{*}{0.343} \\
\hline & PRP Post Elevation D-7 & 35.6585 & & \\
\hline \multirow{2}{*}{ Pair 5} & PRP Post Elevation D-1 & 41.9643 & \multirow{2}{*}{13.45194} & \multirow{2}{*}{0.118} \\
\hline & PRP Post Elevation D-14 & 28.5124 & & \\
\hline \multirow{2}{*}{ Pair 6} & PRP Post Elevation D-7 & 35.6585 & \multirow{2}{*}{7.14613} & \multirow{2}{*}{0.070} \\
\hline & PRP Post Elevation D-14 & 28.5124 & & \\
\hline \multirow{2}{*}{ Pair 7} & PRP Pre Elevation D-1 & 62.3805 & \multirow{2}{*}{0.03603} & \multirow{2}{*}{0.986} \\
\hline & PRP Pre Elevation D-7 & 62.3445 & & \\
\hline \multirow{2}{*}{ Pair 8} & PRP Pre Elevation D-1 & 62.3805 & \multirow{2}{*}{1.79181} & \multirow{2}{*}{0.568} \\
\hline & PRP Pre Elevation D-14 & 60.5887 & & \\
\hline \multirow{2}{*}{ Pair 9} & PRP Pre Elevation D-7 & 62.3445 & \multirow{2}{*}{1.75578} & \multirow{2}{*}{0.311} \\
\hline & PRP Pre Elevation D-14 & 60.5887 & & \\
\hline
\end{tabular}

In the group with injection of PRP after the rat skin flap elevation, the average value on the first day was $42 \%$ with a standard deviation of $34 \%$. On the 7 th day the average is $36 \%$ and the standard deviation is $26 \%$. On the 14th day the average is $28 \%$ and the standard deviation is $22 \%$. The mean area of viable area in the untreated (control) group decreased by $68 \%$ (in the first to last day's observations) as the observation days increased, with differences that were statistically significant. The average viable area of the total flap area on the 1 st day observation was $39 \%$, on the 7 th day observations covering $24 \%$, and on the 14 th day observation $16 \%$ with $\mathrm{p}<0.05$.

The mean area of viable area in the group given injection of PRP after flap elevation decreased to $31 \%$ (in the first to last day's observations) with increasing observation days, although no statistically significant differences were found. The average ratio of the viable area to the total area of the flap on the 1 st day observation was $41 \%$, on the 7 th day observation at $35 \%$, and on the 14 th day observation at $28 \%$ with a $\mathrm{p}$ value $>0.05$.

The mean value of the ratio of the viable area to the total flap area in the group given injection of PRP 24 hours before flap elevation decreased the area of viable area by $3 \%$ (from the first to the last observation) as the observation day increased, although no statistically significant difference was found. The average ratio of the area of the viable area to the total area of the flap on the 1 st day observation was $62 \%$, on the 7 th day observation at $62 \%$, and on the 14 th day observation at $60 \%$ with a $\mathrm{p}$ value $>0.05$.

The mean ratio of the area of viable area to the total area of the flap on the first day post flap elevation of the control group was $38 \%$, in the flap pre-elevation PRP injection group at $62 \%$ and in the PRP injection group post flap elevation was $42 \%$. With the Viability of the 
first day flap in the PRP group the pre elevation was significantly greater than the group without PRP $(\mathrm{p}=0.026)$.

The mean ratio of the area of viable area to total flap area on the 7 th day post flap elevation of the control group was $24 \%$, in the flap pre-elevation PRP injection group at $62 \%$ and in the PRP injection group post flap elevation was $35 \%$. With the viability of the flap in the pre-elevation PRP group it was significantly greater than the group without PRP $(p=0.000)$. And the seventh day viability of the pre-elevation PRP group was significantly greater than the post elevation PRP group $(\mathrm{p}=0.003)$

The ratio of the area of viable to total flap area on the 14 th day post flap elevation of the control group was $16 \%$, in the pre-elevation flap injection group of $60 \%$ and in the PRP injection group post flap elevation was $28 \%$. With flap viability in the pre-elevation PRP group it was significantly greater than the group without PRP $(p=0.000)$. Viability of the pre-elevation PRP flap group was significantly greater than the post elevation PRP group $(\mathrm{p}=0.000)$.

\section{DISCUSSION}

In this study we used homologous PRP from rats which were sacrificed for blood sampling and processed into PRP. With this PRP retrieval method, we get enough PRP to inject all tested animals, without causing tissue reactions. Researchers chose to use homologous PRP because the use of autologous PRP is technically impossible to do for small animals because they do not have enough blood, so we mix blood obtained from 4 different rats and prepare PRP from the blood (Orhan et al 2017).

There was a significant decrease in the percentage of viable area in the control group, but no significant difference was found in the group who received the PRP injection before or after the flap elevation in the first, 7 th and 14th observations. In the control group there was a $68 \%$ reduction in the percentage of the viable area, in the group receiving the PRP injection before the flap elevation was $3 \%$ and in the group receiving the PRP after the flap elevation of $31 \%$.

Table 3. Independent sample t-test

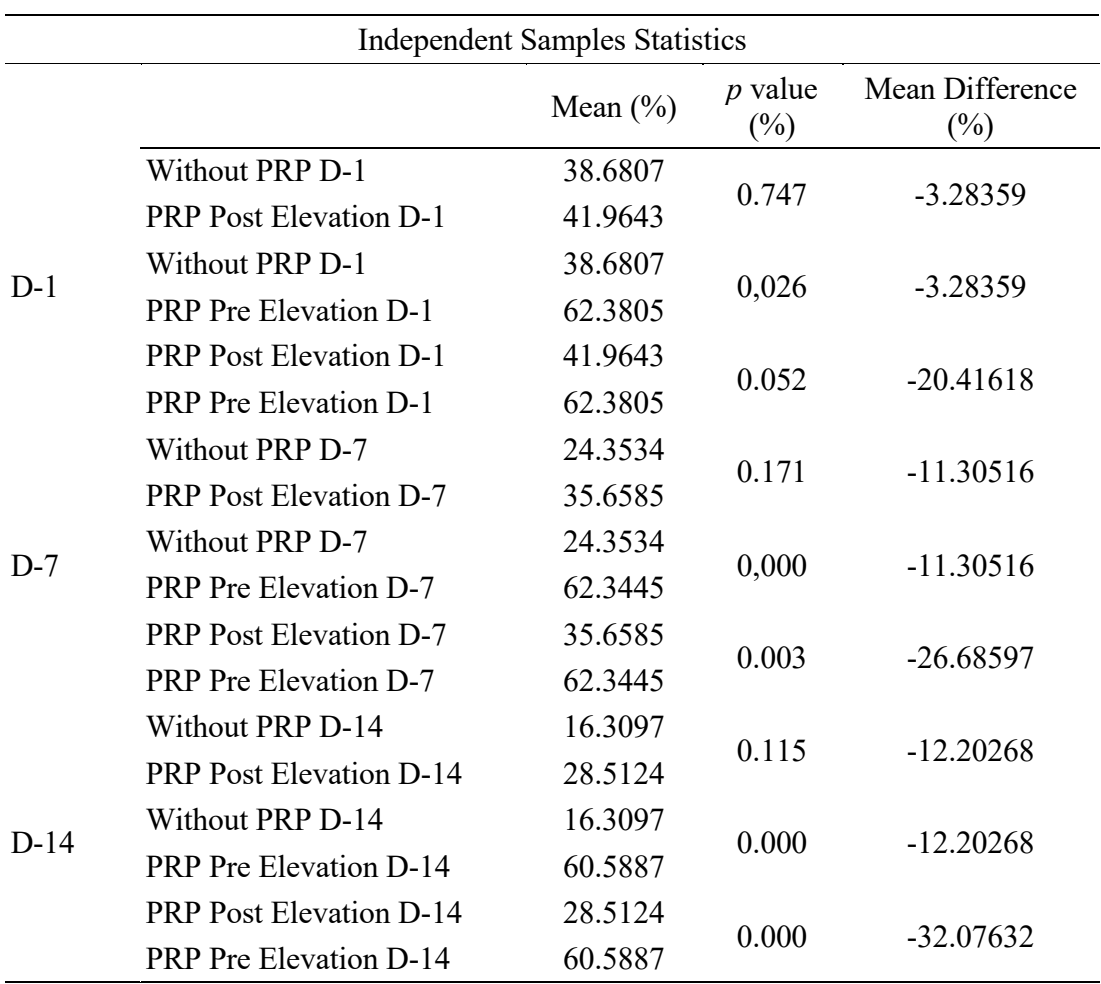

There was a significant difference in the percentage of viable area to the total area of skin flap that was significant between the groups who received injection of PRP before the flap elevation with the control group and the group who received injection of PRP after flap elevation at 7 th and 14 th day observations. Provision of 
PRP before flap elevation increased the ratio of the viable area to the total flap area as much as $258 \%$ to the control group at the 7 th day observation. Provision of PRP before flap elevation increased the ratio of the viable area to the total flap area as much as $177 \%$ for the group receiving the PRP post elevation flap at the 7 th day observation. Provision of PRP before flap elevation increased the ratio of the viable area to the total flap area as much as $375 \%$ to the control group at the 14th day observation. Provision of PRP before flap elevation increased the ratio of the viable area to the total flap area as much as $218 \%$ to the group that received the PRP post elevation flap at the 14th day observation.

In this study, no optimal dose and platelet-rich plasma concentrations were needed to improve the surviving flap area. For further use in clinical practice, different doses and concentrations of PRP may be needed depending on the type and size of the flap. Further research is needed to determine the optimal dose needed to increase the viability of the flap. This is due to an increase in angiogenesis in the group that received the PRP injection on the flap. Kim et al (2013) found that the area of the flap that received injection of PRP had better viability than the control group, whereas microscopic examination showed an increase in mature blood vessel density (Kim et al 2013).

Platelet-rich plasma, which has a platelet concentration of at least $1,000,000$ platelets $/ \mathrm{mm} 3$ in $5 \mathrm{~mL}$ plasma, is strongly correlated with an increase in flap healing (Marx et al 2001). PRP contains a variety of growth factors such as Platelet Derived Growth Factor (PDGF), Transforming Growth Factor- $\beta$ (TGF- $\beta)$, Vascular Endothelial Growth Factor (VEGF), Endothelial Growth Factor (EGF), Insulin-like Growth Factor (IGF1), Endothelial Cell Growth Factor (ECGF) (Alcántara et al 2018). Growth factors released by PRP can increase epithelialization, amount of collagen, wound strength, epidermal regeneration, spur angiogenesis, accelerate homeostasis, therefore the use of PRP can increase the viability of skin flaps (Karayannopoulou et al 2015, Li et al 2012, Takikawa et al 2011).

Li (2012) found a significant increase in PDGF expression after 8 hours, and lasted from 3 to 7 days. The release of PDGF into the skin flap can have a chemotactic effect on monocytes, neutrophils, fibroblasts, mesenchymal stem cells, and osteoblasts. PDGF is also a strong mitogen for fibroblasts and smooth muscle cells and is involved in the wound healing phase (i.e., angiogenesis, fibrous tissue formation, and reepithelialization) (Li et al 2012).
The study by Li (2012) showed that VEGF mRNA expression increased in the group given PRP injection after 8 hours to the next 72 hours. Platelet activation induces VEGF release, an angiogenesis mediator that stimulates endothelial cell proliferation (Kliche et al 2001). VEGF is a permeability factor of blood vessels released from the wound epithelium and extracellular matrix by proteases from endothelial cells, stimulates endothelial cell proliferation and increases vascular permeability. This affects extravasation of plasma proteins and creates a temporary support structure where activated endothelial cells, leukocytes and epithelial cells can migrate (Shweiki et al 1992).

PRP contains more VEGF and induces VEGF expression from endothelial cells, increases microvessel density and prevents tissue necrosis from the initial phase. To fully understand how angiogenesis occurs in skin flaps with platelet-rich plasma treatment, further analysis can be done by microscopic examination and to see blood flow using Doppler laser or flow chart speckle (Wang et al 2016).

\section{CONCLUSION}

PRP injection for pre-elevation flap can increase the viability of extended random skin flaps. There was a significant difference in flap viability between the treatment groups receiving the pre-elevated flap injection of PRP, and the group receiving the PRP injection post elevation flap and the control group. Preelevated PRP injection of flap can increase the viable area to $375 \%$ compared to the control. Pre-elevation PRP flap injection can increase the area of viable area by up to $218 \%$ compared to the group that received post elevation injection of PRP. Post-elevation PRP injection of the flap had a $175 \%$ greater area of viable area compared to the control group, but did not differ statistically. Microscopic examination can be done to see the increase in blood vessel density (angiogenesis), amount of collagen, epidermal regeneration in the administration of PRP on skin flaps and examination of levels of growth factors (VEGF, TGF- $\beta$, PDGF) to see the effect of PRP injection on skin flaps. So that it is expected to be done in patients with vascular disorders and comorbid diseases that affect the quality of blood vessels, so that the success rate of skin flap action can be increased.

\section{REFERENCES}

Alcántara DA, Zaragoza MR, Giménez ED, et al (2018). Platelet rich plasma: new insights for cutaneous wound healing management. J Funct Biomater 9, 10 
Carlson NF, et al (2002). Platelet rich plasma: clinical aplication in dentistry. J Am Dent Assoc 133, 13831386

De Rossi R, Coelho AC, Mello GS, et al (2009). Effects of platelet-rich plasma gel on skin healing in surgical wound in horses. Acta Cir Bras 24, 276-81

Karayannopoulou M, Psalla D, Kazakos G, Loukopoulos P, Giannakas N, Savvas I, KritsepiKonstantinou M, Chantes A, Papazoglou LG (2015). Effect of locally injected autologous platelet-rich plasma on second intention wound healing of acute full-thickness skin defects in dogs. Vet. Comp. Orthop. Traumatol 28, 172-178

Kim HY, Park JH, Han YS, Kim H (2013). The effect of platelet-rich plasma on flap survival in random extension of an axial pattern flap in rabbits. Plast. Reconstr. Surg 132, 85, 2013

Kliche S, Waltenberger J (2001). VEGF receptor signaling and endothelial function. IUBMB Life 52, 61-66

Li W, Enomoto, M, Ukegawa M, Hirai T, Sotome S, Wakabayashi Y, Shinomiya K, Okawa A (2012). Subcutaneous injections of platelet-rich plasma into skin flaps modulate proangiogenic gene expression and improve survival rates. Plast. Reconstr. Surg 129, 858

Marx RE (2001). Platelet-rich plasma (PRP): what is PRP and what is not PRP? Implant Dent 10, 225-8

Orhan E, Uysal AC, Baser E, Keskin D, Yakut CD (2017). The effect of intradermal administration of inactive platelet rich plasma on flap viability in rats. Acta Cir. Bras 32, 280-286

Takikawa M, Sumi Y, Ishihara M, Kishimoto S, Nakamura S, Yanagibayashi S, Hattori H, Azuma R, Yamamoto N, Kiyosawa T (2011). PRP\&F/P MPs improved survival of dorsal paired pedicle skin flaps in rats. J. Surg. Res 170, e189-e196

Shweiki D, Itin A, Soffer D, Keshet E (1992). Vascular endothelial growth factor induced by hypoxia may mediate hypoxia initiated angiogenesis. Nature 359, 843-845

Wang B, Geng, Q, Hu J, Shao J, Ruan J, Zheng J (2016). Platelet-rich plasma reduces skin flap inflammatory cells infiltration and improves survival rates through induction of angiogenesis-An experiment in rabbits. Journal of Plastic Surgery and Hand Surgery 